\title{
Hemoglobin Saint Etienne Found in a Chinese Family
}

\author{
Jian-Xin Xu Hai-Hong Gao \\ Department of Pediatrics, Zhejiang University Jinhua Hospital, Jinhua, China
}

Dear Editor,

Hemoglobin Saint Etienne (Hb St. Etienne), also known as $\mathrm{Hb}$ Istanbul, is a rare inherited disease of hemoglobin which results in loss of heme from the $\beta$-globin chain. So far, Hb St. Etienne has only been described in 4 reports involving 6 patients, and all of them were European [1-4]. In this report, we for the first time identified a family with $\mathrm{Hb}$ St. Etienne in Zhejiang, which indicates that $\mathrm{Hb}$ St. Etienne also exists in Mainland China.
The proband (III 2) was a 33-monthboy who had mild anemia (Hb $87 \mathrm{~g} / \mathrm{L}$ ) with a significantly increased reticulocyte count (11.2\%). Hemoglobin electrophoresis showed the presence of $6.9 \%$ hemoglobin $\mathrm{S}$ and $\mathrm{C}(\mathrm{HbS} / \mathrm{HbC})$ and increased $\mathrm{HbF}$, as well as $\mathrm{HbA}_{2}$ (6 and $17.1 \%$, respectively) (Table 1). It has been reported that his father (II 1) had more severe symptoms and clinical features with moderate anemia $(\mathrm{Hb}<90 \mathrm{~g} / \mathrm{L})$, thrombocyto- penia, and splenomegaly before splenectomy 12 years previously (Table 2). The results from hemoglobin electrophoresis showed that the level of $\mathrm{HbS} / \mathrm{HbC}$ was markedly higher in the proband's father (Fig. 1), and this difference may have been responsible for the difference in disease severity between the proband and his father.

To establish the molecular diagnosis of anemia in the proband, a hotspot mutation

Table 1. Summary of the clinical presentation and laboratory parameters of the patients with Hb St. Etienne reported in this study and in the literature

\begin{tabular}{|c|c|c|c|c|c|c|c|c|}
\hline & \multicolumn{2}{|c|}{ This study } & \multicolumn{2}{|c|}{1972} & \multicolumn{2}{|l|}{2000} & \multicolumn{2}{|c|}{2009} \\
\hline & III 2 & II 1 & $\# 1$ & $\# 2$ & $\# 1$ & $\# 2$ & $\# 1$ & $\# 2$ \\
\hline Gender & M & M & M & M & $\mathrm{F}$ & M & M & $\mathrm{F}$ \\
\hline Age, years & 2.75 & 32 & 8 & 19 & 36 & 13 & 57 & 16 \\
\hline $\mathrm{Hb}, \mathrm{g} / \mathrm{L}$ & 87 & 130 & - & - & 136 & 122 & 135 & 120 \\
\hline PLT,$\times 10^{9} / \mathrm{L}$ & 121 & 382 & - & - & - & - & - & - \\
\hline Ret, \% & 11.2 & 31.5 & - & - & 4.9 & 16 & - & - \\
\hline $\mathrm{MCV}, \mathrm{fL}$ & 96.8 & 103.8 & - & - & 85.7 & 89 & 103 & 116 \\
\hline Splenomegaly & - & + & - & + & + & - & + & + \\
\hline $\mathrm{HbA}, \%$ & 70 & 73.8 & - & - & 60.5 & 62.9 & - & - \\
\hline $\mathrm{HbF}, \%$ & 6 & 2.8 & 19 & - & 0.9 & 0.7 & - & - \\
\hline $\mathrm{HbA}_{2}, \%$ & 17.1 & 1.4 & - & - & 2.6 & 2.4 & - & - \\
\hline $\mathrm{HbS} / \mathrm{HbC}, \%$ & 6.9 & 22 & - & - & 36 & 34 & - & - \\
\hline
\end{tabular}

$\mathrm{Hb}$, hemoglobin; PLT, platelet count; Ret, reticulocytes; MCV, mean corpuscular volume.

\section{KARGER}

(C) 2019 S. Karger AG, Basel

E-Mail karger@karger.com

www.karger.com/aha
Jian-Xin Xu

The Department of Pediatrics

Zhejiang University Jinhua Hospital

Jinhua, Zhejiang 321000 (China)

E-Mail jhyyxjx1640@163.com 
screening assay was performed, with a negative result. The exons of the $H B B$ gene and their flank regions within $50 \mathrm{bp}$ were amplified and sequenced with an ABI 3100 Dx (Thermo Fisher Scientific, USA) for the proband and his family members. It was shown that the proband as well as his father harbored a heterozygousvariant (c.279C $>$ A, p.H93Q), and the variation was segregated with the phenotype in this family (Fig. 2).
Thus, a diagnosis of $\mathrm{Hb}$ St. Etienne was finally established.

To our knowledge, this is the first report of $\mathrm{Hb}$ St. Etienne in Mainland China; it could contribute to better understanding the prevalence and spectrum of $H B B$ gene and related disorders in China. The prevalence of inherited hemoglobin disorders varies considerably with geographical location and ethnic group. In China, consider- ing the cost-effectiveness of testing and other factors, it is common in clinical practice to perform hotspot mutation screening assays of $H B B$ as well as $H B A 1 / 2$ in patients with anemia in Zhejiang as well as in other parts of China to rule out thalassemia and related disorders. The case of $\mathrm{Hb}$ St. Etienne described in this report could not have been confirmed if the $H B B$ gene had not been analyzed via Sanger sequencing.

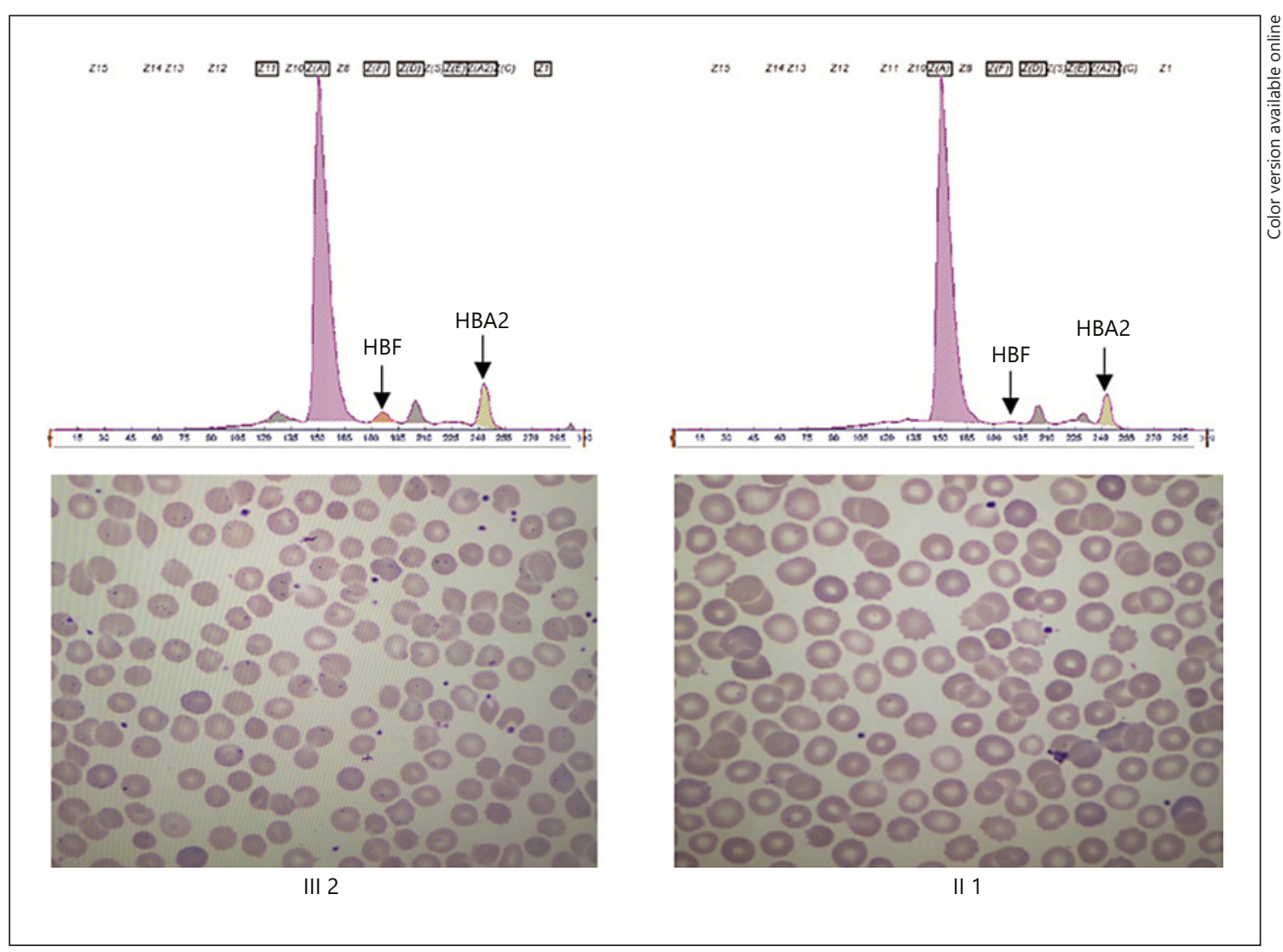

Fig. 1. Hemoglobin analysis and red blood cell morphology of the proband (III 2) and his father (II 1).

Table 2. Laboratory parameters of patient II 1 prior to and after splenectomy

\begin{tabular}{lll}
\hline & Prior to splenectomy & After splenectomy \\
\hline $\mathrm{WBC}, \times 10^{9} / \mathrm{L}$ & 7.3 & 6.2 \\
$\mathrm{~N}, \%$ & 63.2 & 61.8 \\
$\mathrm{HbC}, \times 10^{12} / \mathrm{L}$ & 3.68 & 4.52 \\
$\mathrm{Hb}, \mathrm{g} / \mathrm{L}$ & 89 & 129 \\
$\mathrm{PLT}, \times 10^{9} / \mathrm{L}$ & 63 & 338 \\
\hline
\end{tabular}

WBC, white blood cell count; N, neutrophils; PLT, platelet count. 
Fig. 2. Hemoglobin Saint Etienne found in a Chinese family. a Family pedigree. b Chromatogram of $H B B$ c.279C $>\mathrm{A}$, p.H93Q, by Sanger sequencing.

We suggest that for patients clinically suspected of inherited hemoglobin disorders, whole-gene analysis by Sanger sequencing or target sequencing by next-generation sequencing should be applied, especially for patients with negative hotspot mutation screening results.
I

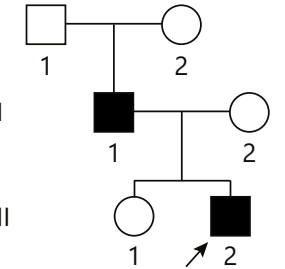

a
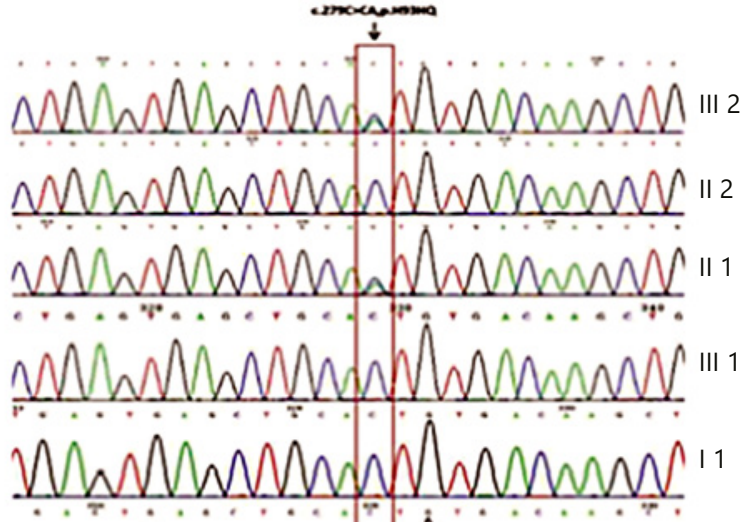

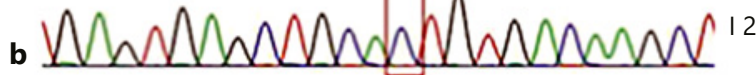

\section{Statement of Ethics}

The authors have no ethical conflicts to disclose.

\section{Disclosure Statement}

The authors have no conflicts of interest to disclose.

\section{References}

1 Aksoy M, Erdem S, Efremov GD, Wilson JB, Huisman TH, Schroeder WA, et al. Hemoglobin Istanbul: substitution of glutamine for histidine in a proximal histidine $(\mathrm{F} 8(92) \beta)$. J Clin Invest. 1972 Sep;51(9):2380-7.

2 Beuzard Y, Courvalin JC, Solal MC, Garel MC, Rosa J, Brizard CP, et al. Structural studies of hemoglobin Saint Etienne $\beta 92$ (F8) his $\rightarrow$ GLN: a new abnormal hemoglobin with loss of $\beta$ proximal histidine and absence of heme on the $\beta$ chains. FEBS Lett. 1972 Oct; 27(1):76-80.
3 de Weinstein BI, Plaseska-Karanfilska D, Efremov GD. Hb Saint Etienne or Hb Istanbul [ $\beta 92(\mathrm{~F} 8) \mathrm{His} \rightarrow \mathrm{Gln}]$ found in an Argentinean family. Hemoglobin. 2000 May;24(2):149-52.

4 Au NH, Wong AY, Vickars L, MacGillivray RT, Wadsworth LD. Two new examples of $\mathrm{Hb}$ St. Etienne $[\beta 92(\mathrm{~F} 8) \mathrm{His} \rightarrow \mathrm{Gln}]$ in association with venous thrombosis. Hemoglobin. 2009; 33(2):95-100. 